\title{
Taiwanese Junior High School Students' Performance on Vocabulary Learning
}

\author{
Ching-Ying Lin \\ Department of Applied English, National Pingtung Institute of Commerce, Taiwan \\ Jin-Wei Ciu \\ Department of Applied English, National Pingtung Institute of Commerce, Taiwan
}

\begin{abstract}
The main purpose of this study was to examine the vocabulary learning in productive and receptive skills by 181 grade 8 junior high students in Taiwan. The performance of students' vocabulary learning on four skills was indicated. The instrument included a vocabulary assessment test. There were 40 English words adopted from Kang Hsuan, Nani and Joy junior high school English textbooks. It involved four parts, listening, speaking, reading and writing. The results reported that significant differences were showed among students' four skills on vocabulary learning. Most subjects were good at listening to the sound of the words. On the other hand, most subjects were failed in pronouncing the English word. Pedagogical implications and suggestions were referred following.
\end{abstract}

Index Terms - vocabulary learning, four skills

\section{INTRODUCTION}

Vocabulary plays a crucial role in listening, speaking, reading and writing. As Wilkins (1972) stated, "Without grammar very little can be conveyed, without vocabulary nothing can be conveyed (p.111)." Limited vocabulary will hinder the ability of non-native speakers to express their ideas and converse; if listening to others, they will not fully comprehend what the speaker is saying; if reading, they will not be able to understand the text; writers will not be able to fully express what they want to share. Hence, learners with an adequate vocabulary are able to put things into context, thereby deriving a deeper understanding of everything said (Stahr, 2008; Neuman \& Dwyer, 2009).

According to the TOEIC and TOEFL tests, the official data show that Taiwanese students' English abilities are still behind compared with those in other Asian countries such as Singapore, Hongkong, China and South Korea (Educational Testing Service, 2006). An in-depth investigation into the approaches used by Taiwanese English teachers has shown that in elementary schools, English classes use role play and games to motivate students. The focus of English learning is on speaking and listening, so students lack training in reading and writing. Whereas, from junior high school to university, de-contextualized materials are used in English classes and there is a strong test-orientated policy. During this period, students are required to focus on reading and writing. The aim of English learning is passing tests. "Repetition and drilling' is deemed the only way to learn English. Under this learning environment, students always rely on short-tern retention rather than long-term retention. Because English is taught in imbalance way, students consider that learning English is more fun and interesting in elementary school. After entering junior high school, gaining admission to good schools, getting high scores and achieving teachers' and parents' expectations are the main goals of students. They only want to know the right answers and practice drills. They are not interested in applying English in their daily life, so there is a decreasing chance for them to achieve a positive outcome regarding EFL learning environment. In Taiwan, which has engaged in English teaching for many years, it is incredibly important that EFL students have the abilities connected with four language skills of the target language. Most Taiwanese people have recognized that English is a bridge to connect to the world. Regardless of its importance in the school exams, the competence of using language is crucial when searching for a job and conducting business with people from different countries.

As a result of the declining birthrate, higher education degrees and the financial tsunami, the family structure has changed. The old idea of raising many children who would help the family is no longer applicable. According to a recent report (Ministry of the Interior, 2011), the birthrate is 0.895 . This number indicates that the birthrate in Taiwan is now less than one child per woman. However, parents' educational backgrounds and knowledge development have been increasing. According to the official data (Council of Labor Affairs, 2009), there were about 70,000 university students in 1995. In 2008, there were more than 230,000 university students in Taiwan. In this current generation, children will get more educational resources. Parents will spend more time and money on cultivating their children's education. The learning environment and social structure have changed significantly during the past five decades.

Under the test-originated policy, students' motivation is generally low for English learning. Most students are strong at repetition and drilling. In this learning process, although they learn many words, students' overall language abilities are still behind. Therefore, it is necessary to explore how individual EFL junior high school students learn vocabulary 
through four skills. The researcher addressed two research questions as follows:

1. Is there a significant difference in the vocabulary learning process in productive skills by individual junior high school EFL students in Taiwan?

2. Is there a significant difference in the vocabulary learning process in receptive skills by individual junior high school EFL students in Taiwan?

\section{LITERATURE REVIEW}

\section{A. Vocabulary Acquisition}

Brown (2007) asserted that ELLs do not always have an adequate knowledge background when absorbing information from textbooks and that having an appropriate grade-level vocabulary in the language learning process is important. Longo and Curtis (2008) reported that students who understood the meanings of various words had a better comprehension than students who knew less. Merely acquiring an abundance of words is not necessarily enough; Broady (2008) posited that a knowledge of vocabulary was not supposed to be limited to memorization or definitions, and the depth of processing should be more fully integrated. Neuman and Dwyer (2009) claimed that the teaching of vocabulary went beyond the identification or labeling of words. It should aid learners to fully comprehend the meaning of a word and the notions it represents. Wallace (2007) indicated that extensive reading played an essential role in acquiring a large vocabulary. The breadth and depth of vocabulary development was connected to reading and listening comprehension. Lee (2009) maintained that children who have a rich vocabulary at an early age were more likely to show better language achievement. As evidence, he maintained that vocabulary played a significant role of literacy development. Furthermore, Anthony (2008) stated that input was crucial for all language learners and is the key for facilitating language output. The input experience of native language acquisition and second language acquisition are similar. Both input and output are important for students to become proficient language learners. Teachers have to give students opportunities to receive new information, and encourage students to verbalize this information. In addition, Nation (2003) revealed that a person's first language represented a significant focal point between communication intent and text, and a crucial factor regarding the four language skills. Nation (2003) provided four steps for learning across the four language skills under equal conditions: meaning focused input, meaning focused output, language focused learning and fluency development. Although language learners have less opportunity to handle the second language outside the classroom, it is still necessary to focus on the second language in the classroom. If this process is followed thoroughly and consistently, the environment will be beneficial and effective for the successful learning of a second language. Using the modes of both input and output, students are made aware of using the second language correctly.

With reference to vocabulary, Tseng and Schmitt (2008) proposed that vocabulary size precedes lexical ability. They maintained that students must be equipped with the opportunities to use the vocabulary they have learned. Gu (1994) reported that vocabulary size could predict a learner's overall language abilities and that there would be certain failure if words learned did not combine both form and meaning. On the other hand, vocabulary acquisition would be successful if learners applied words and associated them with real situations. Also, Stahr (2008) proposed that vocabulary size was important in listening, reading and writing, and that there was a strong correlation among them. Anthony (2008) stated that vocabulary was the fundamental element in speaking and writing. Ma (2004) proposed that a sufficient vocabulary size could assist learners' in their written expression, especially in the case of beginners; however, reading comprehension was most dependent on vocabulary size (Stahr, 2008; Neuman \& Dwyer, 2009; Wallace, 2007). Learners with an adequate vocabulary were better able to understand the contexts. Also, learning the meanings of additional words was not only important for increasing, but also created opportunities for teachers to foster students' word recognition skills (Palumbo \& Sanacore, 2009). On the other hand, Lo, Wang and Hsia (2006) asserted that vocabulary size was not a decisive factor in learning language; they recommended that learners should acquire vocabulary within practical situations rather than memorizing isolated words as this would be more effective.

\section{B. Effective Vocabulary Instruction}

Brown (2007) ascertained that even native speakers find it difficult to understand decontexualized texts. ELLs who did not acquire an adequate background or understanding about what they are reading would find it difficult to be successful readers and would find it more difficult and frustrating than if they were native speakers; he suggested methods to develop ways of scaffolding and accommodation which would assist them in comprehending the contents. Previous studies have proved that learning words related to a specific topic is more effective than learning lexical sets (Thornbury, 2003; Palumbo \& Sanacore, 2009; Brown, 2007). Longo and Curtis (2008) suggested that the direct instruction of the meanings of words taught to students who were struggling with reading was efficient. They further suggested that language teachers should provide multiple opportunities for students to understand the meaning of words from relevant texts. Palumbo and Sanacore (2009) maintained that content-area materials were to be regarded as a guide for teachers to enhance students' comprehension and to broaden their deeper knowledge. They reported that teaching vocabulary directly and dealing with rare words, usually by using content materials, was a beneficial exercise for students. Wallace (2007) emphasized that it was necessary to make sure that ELLs know the meaning of basic words as the lack of vocabulary would impede their comprehension of the text. He also suggested that the process of review and reinforcement in their target language was crucial to improve language ability. Furthermore, conducting teacher-directed 
language development activities and requiring students to read aloud, would improve students' speaking skills.

Phillips, Foote and Harper (2008) were interested in effective instruction for vocabulary development and expressed the opinion that, currently, many teachers' vocabulary teaching is ineffective as they use the method of merely copying the definition of words as their main strategy to teach students new words. To break this inefficient method, they examined five effective vocabulary learning strategies which could be used in class: selecting words, graphic organizing, logic and prediction, synonyms and antonyms and classifying words. They maintained that the purpose of these five recommended strategies was so that the students would learn the full meaning of a given word and learn to use words in meaningful ways through listening, speaking and writing. Teachers need to give students enough opportunities and time to absorb and apply related words from input and output. Making sure students comprehend the full meaning of words instead of being given merely a surface definition, is required. Myers and Chang (2009) ascertained that an approach of grammar instruction and English-Chinese translation is commonly demonstrated by Taiwanese English teachers in Taiwan. In their study, they affirmed that these methods impede students in acquiring an adequate vocabulary. They suggested that employing a multiple-strategy-based approach would stimulate students' vocabulary acquisition and production, and used techniques such as word maps, semantic maps and verbal-visual word association. From the results of interviews, it seems that these had positive outcomes on students' reading, listening, speaking but little effect on writing competence. Griffith and Ruan (2007) identified that the instruction of story innovation was a useful and beneficial strategy to reinforce students' vocabulary and fluency development. The process linked word knowledge and oral reading fluency, and it would aid students in becoming successful readers. By repeating this practice with their favorite reading books, students' literacy development would be improved. Kindle (2009), in his discussion of the role of teachers and the methods they employ, found that reading aloud was an efficient way to teach vocabulary. Huyen and Nga (2003) suggested that learning vocabulary through games is an efficient way to conduct classes. Thornbury (2003) pointed out that using short blocks of text was a suitable approach to learning vocabulary with regard to the skills of listening, reading, writing, and speaking; it provided a strong model for learners to follow in their language learning. Elliott and Olliff (2008) promoted the use of signs to label items in the classrooms; they felt that it would be beneficial as children would then encounter those words frequently. Nixon and John (2009) maintained that a word-sort strategy was a useful way to develop students' critical thinking ability. By having discussions and doing activities in small groups of three or four, students' understanding and retention of words or terms would not be just through memorization.

\section{Spelling Skill and Phonological Awareness}

Several previous studies have shown that phonological awareness is a predictor of reading and spelling development (Furnes \& Samuelsson, 2011; Otaiba, Puranik, Rouby, Greulich, Sidler \& Lee, 2010; Calhoon \& Masterson, 2011; Arndt \& Foorman, 2010). In addition, phonological awareness is related to the sound scheme of language. Former results have shown that a child who is poor at spelling words is likely to also be poor at reading (Otaiba, Puranik, Rouby, Greulich, Sidler \& Lee, 2010; Arndt \& Foorman, 2010). Arndt and Foorman (2010) established a positive connection between reading ability and spelling performance. As mentioned before, students who have reading difficulties normally have spelling problems as well; this seems to be linked to the ability of students to decode several letter - sound matches within the word. Perfetti (1997) explained that spelling was a linguistic skill which required "encoding linguistic forms into written forms. The linguistic units - phonological strings, morphemes, and words - are provided by the spoken language" (p.22). Early spelling skill was important so that any inaccurate letter - sound discernment could be identified and writing could be facilitated. Also, early spelling achievement was highly correlated with later spelling outcomes.

Dich (2009) claimed that spoken word recognition was related to orthography, phonology and literacy acquisition. Puranik and Apel (2010) also asserted that orthographic knowledge was a decisive factor in spelling performance; in evidence, they found that positive results in letter writing skills are related to children's orthographic knowledge development. Calhoon and Masterson (2011) pointed out that students utilized not only their phonemic knowledge but also alphabetic knowledge when they encountered words of which they were unsure. Therefore, developing phonemic awareness is a necessary basic skill to identify and apply the sound components when speaking and writing words. To improve students' spelling performance, teachers need to assess where students' were experiencing difficulties and then give them direct spelling instruction. Chen and Yeh (2004) indicated that training in the skills of spelling while focusing on meaningful words is an effective approach. Arndt and Foorman (2010) suggested that teaching spelling rules and patterns was necessary for enhancing students' spelling and reading knowledge. This essential knowledge would aid students in reading comprehension and in acquiring a larger vocabulary.

\section{Methodology}

\section{A. Subjects}

The subjects of this study were 181 grade 8 junior high school EFL students in southern Taiwan, all of whom had been learning English for at least three years. The researcher chose them form two public junior high schools.

\section{B. Instruments}


In terms of the design of the vocabulary assessment test, the researcher initially picked 80 words from the three English textbooks. Kang Hsuan, Nani and Joy versions were adopted. Then, the researcher recruited 60 grade 8 junior high school students to do this test. According to the students' results, the researcher removed the top $25 \%$ correct answers and bottom $25 \%$ incorrect answers. There were the only 40 words presented in the vocabulary assessment test. Each correct answer scored 2.5 and the total score was 100. The vocabulary assessment test was categorized into four parts: listening, speaking, reading and writing.

\section{Procedures}

There were four main parts to the vocabulary assessment test. To assess the internal test reliability, the researcher applied Cronbach's alpha to examine all questions. The results showed that the overall questions were at .95; for the separate parts, listening was at .96 , speaking was at .93 , reading was at .91 and writing was at .91 .

In the beginning of the vocabulary assessment test, the researcher explained the main reason for doing these tests and then distributed the vocabulary assessment tests to the students. In the speaking part, each individual student had to pronounce the key word to the researcher. In the reading part, the students had to write down the Chinese meaning of the English word. In the listening part, the researcher played the CD and the students had to select the right answer from a multiple-choice. In the writing part, the students had to write down the spelling of the English word according to the Chinese meaning. The data collection procedure is given below (see Table 1)

TABLE 1

DATA COLLECTION PROCEDURES

\begin{tabular}{|l|l|l|}
\hline Step & Data Collection & Time \\
\hline 1 & Execute a pretest on 60 grade 8 junior high school students & \\
2 & Select 181 grade 8 junior high school students in southern Taiwan & \\
3 & Solicit the teachers' permission to do survey & 1 minute \\
4 & Explain the meaning of the vocabulary assessment test for each class & 25 minutes \\
5 & Do the speaking test & 15 minutes \\
6 & Do the reading test & 6 minutes \\
7 & Do the listening test & 15 minutes \\
8 & Do the writing test & \\
\hline
\end{tabular}

\section{Data Analysis}

The data were analyzed by using descriptive statistics, pair sample t-tests and Cronbach's alpha. Cronbach's alpha was used to examine inter reliability of the vocabulary assessment test. Descriptive statistics included mean and SD. Pair sample t-test showed correlation and differences from each group.

\section{Results}

1. Is there a significant difference in the vocabulary learning process in productive skills by individual junior high school EFL students in Taiwan?

TABLE 2

THE MEAN AND SD OF PRODUCTIVE SKILLS

\begin{tabular}{lll}
\hline Productive Skills & Mean & SD \\
\hline Writing & 50.64 & 33.22 \\
\hline Speaking & 42.12 & 33.72 \\
\hline
\end{tabular}

The result showed the mean of spelling the right English word was higher (mean $=50.64)$. However, the mean of pronouncing the right English word was lower (mean $=42.12)$ (see Table 2).
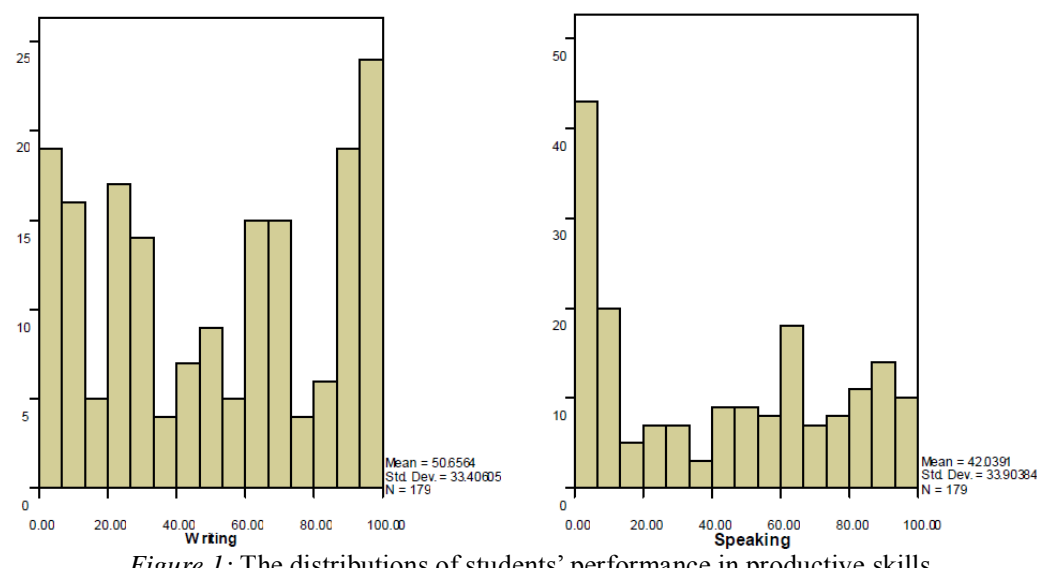

Figure 1: The distributions of students' performance in productive skills

In Figure 1, the histograms revealed the detailed results of the students' performance distribution in productive skills. 
The results showed a moderate distribution for the Writing part. However, as Figure 1 showed, most students achieved low scores on their speaking performance. Many students had difficulty in pronouncing the English words.

2. Is there a significant difference in the vocabulary learning process in receptive skills by individual junior high school EFL students in Taiwan?

TABLE 3

THE MEAN AND SD OF PRODUCTIVE SKILLS

\begin{tabular}{lll}
\hline Receptive Skills & Mean & SD \\
\hline Listening & 77.47 & 26.80 \\
\hline Reading & 50.73 & 33.67 \\
\hline
\end{tabular}

Table 3 showed that junior high school students were good at listening to the sound of the word $(\mathrm{mean}=77.47)$. The performance of reading the English word and translating it into Chinese was moderate $($ mean $=50.73)$,
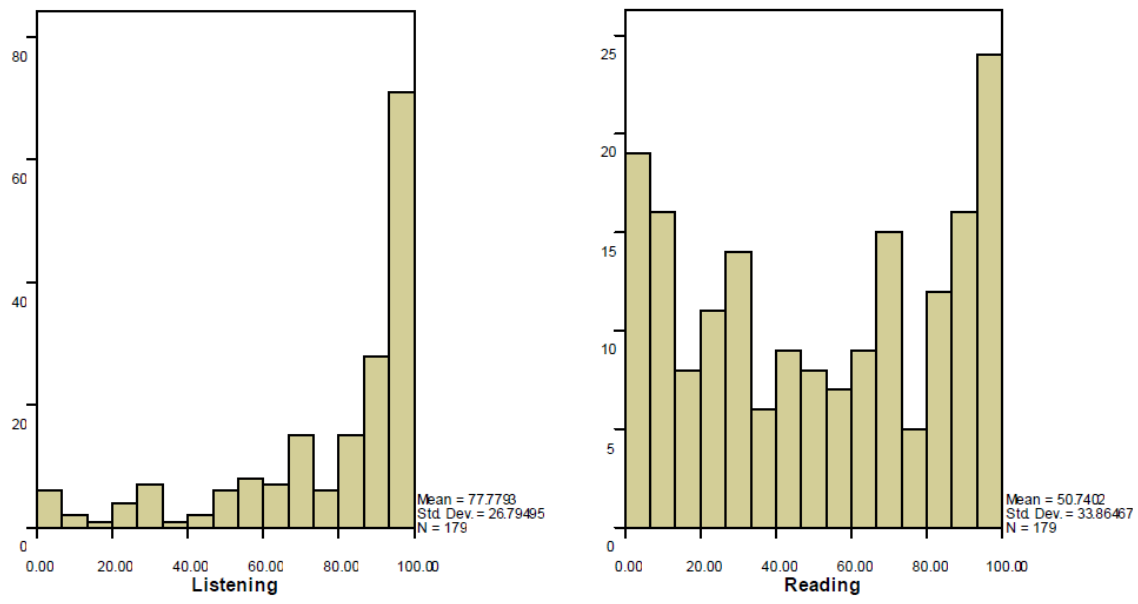

Figure 2: The distributions of students' performance in receptive skills

In Figure 2, the histograms revealed the detailed results of the students' performance distribution for receptive skills. Most students showed strong listening skills and the results revealed that most of the students got high scores for their listening part. Whereas, the results indicated moderate distribution for the reading part.

TABLE 4

THE RESULTS OF A PAIRED SAMPLES CORRELATION AND T-TEST IN PRODUCTIVE AND RECEPTIVE SKILLS

\begin{tabular}{|c|c|c|c|c|c|c|c|}
\hline \multirow[t]{2}{*}{ Four Skills } & \multirow[t]{2}{*}{$\mathrm{N}$} & \multirow[t]{2}{*}{ MR } & \multirow[t]{2}{*}{ SSD } & \multirow[t]{2}{*}{ Std. Error } & \multicolumn{3}{|c|}{ Paired samples t-Test } \\
\hline & & & & & $\mathrm{t}$ & df & Sig. \\
\hline Speaking-Reading & 181 & .870 & 17.21 & 1.279 & -6.727 & 180 & $.000 *$ \\
\hline Speaking-Listening & 181 & .756 & 22.11 & 1.643 & -21.50 & 180 & $.000 *$ \\
\hline Speaking-Writing & 181 & .870 & 17.05 & 1.267 & -6.724 & 180 & $.000 *$ \\
\hline Reading-Listening & 181 & .746 & 22.48 & 1.671 & -15.99 & 180 & $.000 *$ \\
\hline Reading-Writing & 181 & .973 & 7.79 & .579 & .143 & 180 & .886 \\
\hline Listening-Writing & 181 & .766 & 21.38 & 1.589 & 16.87 & 180 & $.000 *$ \\
\hline
\end{tabular}

A paired samples t-Test was used to probe into whether there were significant differences among the six groups (see Table 4). According to the findings, there was a significant difference between speaking and reading $(\mathrm{p}=.000<.05)$, between speaking and listening $(p=.000<.05)$, between speaking and writing $(p=.000<.05)$ and between reading and writing $(\mathrm{p}=.000<.05)$. Finally, there was also a significant difference between listening and writing $(\mathrm{p}=.000$ $<.05)$. However, there was no significant difference between reading and writing $(\mathrm{p}=.886>.05)$.

\section{DISCUSSION}

In terms of research questions, the findings showed that the junior high school students were strong at listening to the sound of words but poor at pronouncing the words. Reading and writing performance were moderate. This phenomenon was probably caused by current teaching styles. Test-orientated policy and grammar instruction were the main ways used in schools to motivate students to learn English. In Myers and Chang's (2009) study, they mentioned that grammar instruction and English-Chinese translation were usually approached in Taiwanese English classes. In this learning environment, students' language learning achievement would be impeded. Students seldom actually spoke English in class or after class. On the other hand, listening training was obviously done when students started learning English and students got used to identifying the sound of English words. Because their teachers would repeat words many times. Also, reading and writing skills were the main focus of language learning, especially in the test- orientated policy that has been implemented in Taiwan. It was probably because reading words and writing them down was stressed in 
English tests. The difference between reading and writing performances in this research was not significant.

\section{CONCLUSION}

Regarding the students' four skills on vocabulary learning, most students failed on verbalization. However, they were successful in their listening skills and could recognize the sound of words. In traditional Taiwanese culture, most Taiwanese students would be afraid of losing face and being laughed at by others if they spoke incorrect English. Under this kind of worse situation, most students prefer to be listeners during class, listening training is practiced more than speaking. Moreover, the English learning environment is still not well-developed in Taiwan. Students lack opportunities to speak English in their daily lives. This deficient situation still exists.

\section{Pedagogical IMPlications}

It is noted that speaking is the weakest part of the students' English language ability. The main point is that students still speak Chinese during English classes and this lack of practice will inevitably limit students' speaking skills. As Nation (2003) observed, even though language learners may have few opportunities to use their second language outside the classroom, using it during class-time is still necessary. If this process is performed thoroughly and consistently, the environment will be conducive to learning a second language successfully. Through input and output, students will become aware of how to use second language correctly. Therefore, it is important to give students enough opportunities and the encouragement to verbalize as often as possible. In attempting to create an environment conducive to learning the language, at least students should be expected to speak English in English classes. With such stimulations, students will be pushed to speak English, ensuring regular and ongoing progress.

\section{LIMITATIONS OF THE STUDY}

First, the subjects were 181 junior high school students. The sample size was small. Therefore, the sample was not representative of all junior high school students in Taiwan. Second, grade 8 students were the subjects in this study; grade 7 and grade 9 junior high school students were not recruited. The results are not representative of all the students and can only explain the attributes of grade 8 junior high school students. Third, students from the northern, western and eastern areas were not considered. The southern area is only one part of Taiwan and the findings from this area cannot necessarily be extrapolated to other regions. Fourth, with the vocabulary assessment tests, only three junior high school English textbooks were adopted and the vocabulary assessment test only comprised 40 items. The results as interpreted in the current study might be different if adopting other versions of consisting vocabulary assessment test and a bigger vocabulary items were used. As mentioned, the verbal part of a vocabulary assessment test may cause the students to feel pressure. This variable could influence the students' speaking performance.

\section{SugGestions For Future StUdies}

First, there were only 181 junior high school students used in the research, which is not a big enough sample size. In future research, the sample size could be increased to explore whether sample size would influence the final results. Second, this study only recruited grade 8 students; grade 7 and grade 9 students were not recruited. Therefore, grade 7 and grade 9 students could be included in future research to examine the factor of different ages on vocabulary learning. Third, this study only recruited students from southern Taiwan. Future research could recruit students from northern, eastern and western areas of Taiwan to compare the influence of students from different areas on vocabulary learning. Fourth, the instrument of vocabulary assessment tests only adopted three junior high school English textbooks, and there were only 40 items in the vocabulary assessment test. A future study could adopt other versions and also a test with a bigger vocabulary base. The factor of different versions and the size of vocabulary assessment test may be significant and could influence the results of the whole research. With regard to the verbal part of the vocabulary assessment test, the stressful one-on-one situation could be changed by using a recording. This may decrease the students' pressure and their verbal performance may be improved.

\section{REFERENCES}

[1] Anthony, A. R. B. (2008). Output strategies for English-language learners: theory to practice. The Reading Teacher, 61(6), 472-482.

[2] Arndt, E. J., \& Foorman, B. R. (2010). Second graders as spellers: what types of errors are they making? Assessment for Effective Intervention, 36(1), 57-67.

[3] Ball, C. (2009). Monitoring children growth in early literacy skills: effects of feedback on performance and classroom environments. Education and treatment of children, 32(2), 189-212.

[4] Basic Competence Test. (2010). Retrieved July 20, 2011, from http://www.bctest.ntnu.edu.tw/

[5] Broady, E. (2008). Fragmentation and consolidation: recent articles on vocabulary acquisition. Language Learning Journal, $36(2), 259-265$.

[6] Brown, C. L. (2007). Support English language learning in content-reading. Reading Improvement, 44(1), 32-39.

[7] Brown, C. L. (2007). Strategies for making social studies texts more comprehensible for English-language learners. The Social 
Studies, 5, 185-188.

[8] Calhoon, M. B., \& Masterson, J. J. (2011). Lexical analysis of words on commonly used standardized spelling assessments. Assessment for Effective Intervention, 36(2), 80-93.

[9] Catalan, R. M. J. (2003). Sex differences in L2 vocabulary learning strategies. International Journal of Applied Linguistics, 13(1), 55-77.

[10] Chen, H. C., \& Yen, H. C. (2004). College student's difficulties and strategies in EFL vocabulary learning. Journal of Wu Fen, $12,107-114$.

[11] College Entrance Examination Center. (2008). Retrieved July 20, 2011, from http://www.ceec.edu.tw/

[12] College Entrance Examination Center. (2010). Retrieved July 20, 2011, from http://www.ceec.edu.tw/

[13] Council of Labor Affairs (2009). Retrieved July 20, http://www.cla.gov.tw/cgi-bin/siteMaker/SM_theme?page=41d35566

[14] Dich, N. (2009). Individual differences in the size of orthographic effects in spoken word recognition: the role of listeners' orthographic skills. Applied Psycholinguistics, 32(1), 169-186.

[15] Educational Testing Service. (2006). Retrieved July 20, 2011, from http://www.toeic.com.tw/toeic_news_page.jsp?type=4

[16] Elliot, E. M., \& Olliff, C. B. (2008). Development appropriate emergent literacy activities for young children: adapting the early literacy and learning model. Early Childhood Education Journal, 35(6), 551-556.

[17] Furnes, B., \& Samuelsson, S. (2011). Phonological awareness and rapid automatized naming predicting early development in reading and spelling: Results from a cross-linguistic longitudinal study. Learning and Individual differences, 21, 85-95.

[18] Griffith, P. L., \& Ruan, J. (2007) Story innovation: an instructional strategy for developing vocabulary and fluency. The Reading Teacher, 6(14), 334-338.

[19] Gu, Y. (1994). Vocabulary learning strategies of good and poor Chinese EFL learners. Poster session presented at the annual meeting of the Teacher of English to Speakers of Other Languages, Baltimore, MD.

[20] Huyen, N. T. T., \& Nga, K. T. T. (2003). The effectiveness of learning vocabulary through games. The Asian EFL Journal, 5(4), $1-15$.

[21] Kindle, K. J. (2009). Vocabulary development during read-alouds: primary practices. The Reading Teacher, 63(3), $202-211$.

[22] Lee, J. (2009). Size matters: early vocabulary as a predictor of language and literacy competence. Applied Psycholinguistics, 32(1), 69-92.

[23] Lee, K. R., \& Oxford, R. (2008). Understanding EFL learner's strategy use and strategy awareness. The Asian EFL Journal, $10(1), 7-32$.

[24] Liao, Y. F. (2004). A survey study of Taiwan EFL freshmen's vocabulary learning strategies. Journal of National Pingtung University of Education, 21, 271-288.

[25] Longo, A. M., \& Curtis, M. E. (2008). Improving the vocabulary knowledge of struggling readers. The NERA Journal, 44(1), 23-28.

[26] Lo, M. L., Wang, D. C., \& Hsia, C. S. (2006). An investigation of technical college EFL students' vocabulary learning concepts. English Teaching and Culture, 2, 30-41.

[27] Ma, Z. X. (2004). The necessity of intensifying English vocabulary teaching in the remote minority area college English teaching. The Asian EFL Journal, 6(2), 1-6.

[28] Ministry of Education. (2004). Retrieved June 2, 2011, from http://search.moe.gov.tw/hysearch/cgi/m_query.exe

[29] Ministry of Education. (2011). Retrieved June 2, 2011, from http://www.edu.tw/

[30] Ministry of the Interior. (2011). Retrieved June 2, 2011, from http://www.moi.gov.tw/

[31] Myers, J., \& Chang, S. F (2009). A multiple-strategy-based approach to word and collocation acquisition. IRAL, 47(2), 179-207.

[32] Nation, P. (2003). The role of the first language in foreign language learning. The Asian EFL Journal, 1-8.

[33] Neuman, S. B., \& Dwyer, J. (2009). Missing in action: vocabulary instruction in pre-k. The Reading Teacher, 62(5), $384-392$.

[34] Nixon, S., \& Fishback, J. (2009). Enhancing comprehension and retention of vocabulary concepts through small-group discussion: probing for connections among key terms. Journal of College Science Teaching, 38(5), 18-21.

[35] Otaiba, S. A., Puranik, C. S., Rouby, D. A., Greulich, L., Sidler, J. F., \& Lee, J. (2010). Predicting kindergarteners' end-of-year spelling ability based on their reading, alphabetic, vocabulary, and phonological awareness-skills, as well as prior literacy experiences. Learning Disability Quarterly, 33(3), 171-183.

[36] Palumbo, A., \& Sanacore, J. (2009). Helping struggling middle school literacy learners achieve success. Clearing House, 82(6), 275-280.

[37] Perfetti, C. A. (1997). The psycholinguistics of spelling and reading. In C. A. Perfetti, L. Rieben, \& M. Fayol (Eds.), Learning to spell: Research, theory, and practice across languages (pp. 21-38). Mahwah, NJ: Erlbaum.

[38] Phillips, D. C. K., Foote, C. J., \& Harper, L. J. (2008). Strategies for effective vocabulary instruction. Reading Improvement, 45(2), 62-68.

[39] Puranik, C., \& Apel, K. (2010). Effect of assessment task and letter writing ability on preschool children's spelling performance. Assessment for Effective Intervention, 36(1), 46-56.

[40] Stahr, L. S. (2008). Vocabulary size and the skills of listening, reading and writing. Language Learning Journal, 36(2), 139-152.

[41] The Language Training \& Testing Center. (2004). Retrieved July 20, 2011, from https://www.gept.org.tw/Exam_Intro/t02_words.asp

[42] Thornbury, S. (2003). Teaching vocabulary using short texts 1. The Asian EFL Journal, 5(4), 1-6.

[43] Tseng, W. T., \& Schmitt, N. (2008). Toward a model of motivated vocabulary learning: a structural equation modeling approach. Language Learning, 58(2), 357-400.

[44] Wallace, C. (2007). Vocabulary: the key to teaching English language learners to read. Reading Improvement, 44(4), 189-193.

[45] Wei, M. (2007). An examination of vocabulary learning of college-level learners of English in China. The Asian EFL Journal, 9 , 93-114. 
[46] Wilkins, D. A. (1972). Linguistics in language teaching. London: Edward Arnold.

[47] Yang, M. N. (2007). Language learning strategies for junior college students in Taiwan: investing ethnicity and proficiency. The Asian EFL Journal, 9, 35-57.

Ching-Ying Lin is an assistance professor, Department of Applied English, National Pingtung Institute of Commerce, Taiwan.

Jin-Wei Ciu is a graduate student, Department of Applied English, National Pingtung Institute of Commerce, Taiwan. 